\title{
Mesenteric Meckel's Diverticulum - A Rare Entity
}

\author{
Preeti Prabhakarrao Thute ${ }^{1}$, Bhaurao Champatrao Bakane ${ }^{2}$, Harsha Atul Keche ${ }^{3}$, \\ Vilas Keshavrao Chimurkar4, Darshna Gulabrao Fulmali ${ }^{5}$
}

1,2,3,5 Department of Anatomy, Jawaharlal Nehru Medical College, Sawangi (Meghe), Wardha, Maharashtra, India. ${ }^{4}$ Department of Surgery, Jawaharlal Nehru Medical College, Sawangi (Meghe), Wardha, Maharashtra, India.

\section{INTRODUCTION}

Johann Friedrich Meckel, in 1809, described the embryological structure resulting from the failure of involution of the vitelline duct which is named after him as Meckel's diverticulum. ${ }^{1}$ Meckel's diverticulum with a prevalence of $2 \%$ in the population is the most common embryological malformation of the gastrointestinal tract. It is a consequence of failure of complete obliteration of the vitelline duct between five to eight weeks of gestation, leaving behind a true diverticulum of the small intestine with all the histological layers of small intestine, has a separate extension of peritoneal fold for blood supply, arises from the ileum along its antimesenteric border and located approximately two feet proximal to the ileocecal junction. Rule of two is applicable to Meckel's diverticulum i.e., it is approximately two inches long, may contain two types of tissue which is heterotopic i.e., gastric and pancreatic and located approximately two feet proximal to the ileocaecal junction ${ }^{2}$. The anti-mesenteric location is described as one of the cardinal finding in defining Meckel's diverticulum. The mesenteric location of a Meckel's Diverticulum (MD) is a rare finding and only fourteen cases have been reported in the literature so far since 1941, when Chaffin first reported it.1,2 Over recent decades one of the cardinal diagnostic features of Meckel's diverticulum, the antimesenteric location, is challenged as cases of mesenteric location has been reported.

\section{PRESENTATION OF CASE}

A 33-year-old male presented with pain in right lower abdomen, vomiting and fever for last 2 days. He had similar complaints two months before. On admission his vitals were stable except temperature $\left(101^{\circ} \mathrm{F}\right)$. Abdominal examination revealed scaphoid abdomen with rebound tenderness at McBurney's point. No guarding rigidity or free fluid in abdomen. Haematological investigations showed polymorphonuclear leukocytosis. Biochemical investigations were within normal limit. Ultrasound of abdomen revealed probe tenderness in right iliac fossa with visualization of noncompressible tubular aperistaltic structure measuring $8 \mathrm{~mm}$ in diameter.
Corresponding Author: Dr. Preeti Prabhakarrao Thute, Tathastu, Infront of Ajit Sunder Palace Apartment, Laxminagar, Wardha, Maharshtra, India.

E-mail: b_bakane@rediffmail.com

DOI: $10.14260 / \mathrm{jemds} / 2020 / 783$

How to Cite This Article:

Thute PP, Bakane BC, Keche HA, et al. Mesenteric Meckel's diverticulum - a rare entity. J Evolution Med Dent Sci 2020;9(47): 3572-3574, DOI:

10.14260/jemds/2020/783

Submission 03-08-2020,

Peer Review 06-10-2020,

Acceptance 12-10-2020,

Published 23-11-2020.

Copyright (C) 2020 Preeti Prabhakarrao Thute et al. This is an open access article distributed under Creative Commons Attribution License [Attribution 4.0 International (CC BY 4.0)] 


\section{CLINICAL DIAGNOSIS}

Considering clinical and radiological findings the diagnosis of acute appendicitis was made.

\section{DISCUSSION OF MANAGEMENT}

Considering the diagnosis of acute appendicitis, appendicectomy was planned. The abdomen was opened by McBurney's incision. Exploration revealed long, turgid, inflamed retrocaecal appendix with minimal free fluid. Appendicectomy was performed and traced the terminal ileum from ileocaecal junction for Meckel's diverticulum. A diverticulum was found along the mesenteric border of the terminal ileum 2 feet away from the ileocaecal junction which was 2 inches long and non-inflamed. (Figure 1) Diverticulectomy was performed. The post-operative recovery of the patient was uneventful.

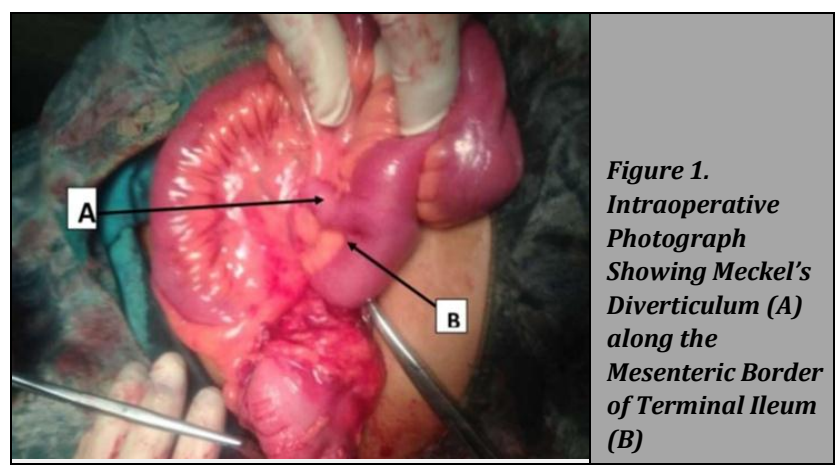

PATHOLOGICAL DISCUSSION

The histopathology of specimen of appendix was reported as appendicitis and that of diverticulum confirmed it as Meckel's diverticulum (39 $\mathrm{mm}$ long and $11 \mathrm{~mm}$ in diameter) without any complications. The tissue was showing all the histological features of small intestine with mild hyperplasia at places. (Figure 2)

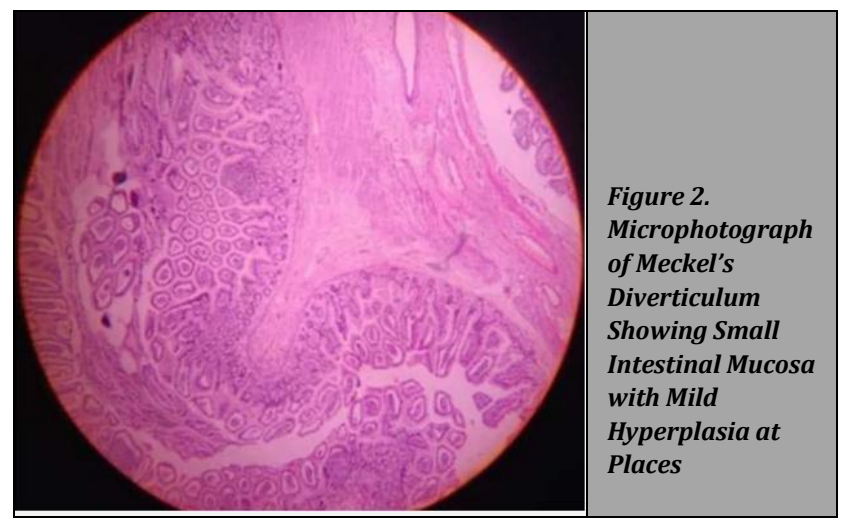

FINAL DIAGNOSIS

Acute appendicitis with uncomplicated Mesenteric Meckel's diverticulum.

\section{DISCUSSION}

The commonest location of Meckel's diverticulum is on the part of terminal ileum along its antimesenteric border.

Chaffin, in 1941 first described a case of mass showing inflammatory changes located along the mesenteric border of the terminal ileum. ${ }^{1}$ Kurzbart et al in 2002, described a case of infant with an originally patent vitelline duct which obliterated at three months of life leaving behind Meckel's diverticulum along the mesenteric border which supports the possibility of the mesenteric Meckel's diverticulum. ${ }^{3}$

In 2008 Sarioglu-Buke A. et al, had postulated that the mesenteric origin of Meckel's diverticulum to be due to the presence of a very short vitelline artery, which form a mesodiverticular band pulling the diverticulum towards the mesenteric border during its rapid phase of growth. ${ }^{4}$

The antimesenteric location of the Meckel's diverticulum has been a classical diagnostic criterion. However, since 1941, few cases of location along the mesenteric border of ileum has been reported. 5

Donellan WL et al., in their report described congenital and inflammatory adhesions as the aetiology of mesenteric location. ${ }^{6}$ The possibility of the persistent short vitelline artery forming a mesodiverticular band which during growth phase might have diverted the diverticulum away from the antimesenteric edge. In our case and studies of other authors such as Mohanty PK et al, Mwila PK et al histopathological examination did not reveal a meso-diverticular band or a vitelline artery, and features of inflammation.7,8

In 2004, Segal et al published a case of appendicitis with an incidental finding of mass with inflammatory changes originating from the mesenteric border of the part of the terminal ileum proximal to the ileocecal junction. But the diagnosis of duplication cyst or Meckel's diverticulum (atypical) with occluded lumen because of inflammatory changes could not be inferred with certainty as the presence of gastric mucosa in the mass could not absolve the diagnosis of an enterogenous cyst. ${ }^{9}$

In 2008 Sarioglu-Buke et al reported a case presented with painless rectal bleeding who had undergone surgery found to have diverticulum along the mesenteric edge with direct communication with the part of the ileum. In addition to this, separate blood vessels were found supplying the diverticulum. ${ }^{10}$

In our case the diverticulum was found to have separate blood supply through a pedicle which supports the diagnosis of atypical Meckel's diverticulum and not an enterogenous or duplication cyst.

McGrath AK et al reported variable clinical presentation from asymptomatic incidental intra-operative diagnosis, to non-specific abdominal pain, per rectal bleeding, intussusception, diverticulitis, and perforation. ${ }^{11}$

Clinical diagnosis of Meckel's diverticulum is very difficult. Even though there are different diagnostic modalities like endoscopy, angiography, contrast radiological studies and scintigraphy, the Meckel's diverticulum are diagnosed intraoperatively. 12

Laparoscopic diagnosis and definitive treatment are safe, affordable, and efficient modality for the symptomatic Meckel's diverticulum with precise operative diagnosis, easy access with minimal trauma, a very few intraoperative and 
postoperative complications with early postoperative recovery. ${ }^{13}$

There are chances that this abnormally located Meckel's diverticulum erode into mesentery causing bleeding and other complications. Symptomatic mesenteric Meckel's diverticulum patients should go for diverticulectomy or small bowel resection. But in case of accidental finding during other abdominal surgery, a diverticulectomy via open or laparoscopic approach should be performed. ${ }^{14}$

\section{CONCLUSIONS}

Surgeons should look for Meckel's diverticulum not only along antimesenteric border but also mesenteric border so that though rare Meckel's diverticulum should not be missed. This rare variant adds new point in rule of two i.e., two locations: along the anti-mesenteric and mesenteric ileal borders. When Meckel's diverticulum is incidentally encountered during intraabdominal surgery diverticulectomy or small bowel resection should be done to avoid the complication of erosion of closely related mesentery leading to severe intraabdominal bleeding.

Financial or other competing interests: None.

Disclosure forms provided by the authors are available with the full text of this article at jemds.com.

\section{REFERENCES}

[1] Hollinshead WH. The jejunum, ileum, and colon. In: Hollinshead WH, ed. Anatomy for surgeons. Vol 2. New York: Harper and Row 1971.

[2] Mai JYL, Balasooriya J. Mesenteric Meckel's diverticulitis perforation with pneumoperitoneum and faeculant peritonitis. J Univer Surg 2020;8(1):2.

[3] Kurzbart E, Zeitlin M, Feigenbaum D, et al. Rare spontaneous regression of patent omphalomesenteric duct after birth. Arch Dis Child Fetal Neonatal Ed 2002;86(1):F63.

[4] Sarioglu-Buke A, Corduk N, Koltuksuz U, et al. An uncommon variant of Meckel's diverticulum. Can J Surg 2008;51(2):E46-7.

[5] Wani I, Khan N, Nagash S, et al. Mesenteric Meckel's diverticulum. Turk J gastroenterology 2013;24(2):187-9.

[6] Donellan WL. Meckel's Diverticulum and related anomalies. In: Donellan WL, Burrington JD, Kimura K, et al, eds. Abdominal surgery of infancy and childhood. Luxemburg: Harwood Academic Publishers 2001;12:1-4.

[7] Mohanty PK, Panda SS, Das RR, et al. Mesenteric location of Meckel's diverticulum: is it really uncommon? Saudi J Health Sci 2014;3(3):166-7.

[8] Mwila PK, Kakudji BK, Mosimanyane N, et al. Meckel's diverticulum located at the mesenteric edge of the ileum in an adult male: case report. PAMJ Clinical Medicine 2019;1:36.

[9] Segal SD, Albrecht DS, Belland KM, et al. Rare mesenteric location of Meckel's diverticulum, a forgotten entity: a case study aboard USS Kitty Hawk. Am Surg 2004;70(11):985-8.

[10] Sarioglu-Buke A, Corduk N, Koltuksuz U, et al. An uncommon variant of Meckel's diverticulum. Can J Surg 2008;51(2):E46-7.

[11] McGrath AK, Suliman F, Thin N, et al. Adult intussusception associated with mesenteric Meckel's diverticulum and antimesenteric ileal polyp. BMJ Case Rep 2019;12(9):e230612.

[12] Rivas H, Cacchione RN, Allen JW. Laparoscopic management of Meckel's diverticulum in adults. Surg Endosc 2003;17(4):620-2.

[13] Shalaby RY, Soliman SM, Fawy M, et al. Laparoscopic management of Meckel's diverticulum in children. J Pediatr Surg 2005;40(3):562-7.

[14] Levack MM, Fiedler AG, Kaafarani H, et al. Perforation of a mesenteric Meckel's diverticulum. Journal of Surgical Case Reports 2018;6:1-2. 